\title{
Understanding personal learning networks: Their structure, content and the networking skills needed to optimally use them
}

Citation for published version (APA):

Rajagopal, K., Joosten-ten Brinke, D., Van Bruggen, J., \& Sloep, P. (2012). Understanding personal learning networks: Their structure, content and the networking skills needed to optimally use them. First Monday, 17(1), 1-12. https://doi.org/10.5210/fm.v17i1.3559

DOI:

10.5210/fm.v17i1.3559

Document status and date:

Published: 06/01/2012

Document Version:

Publisher's PDF, also known as Version of record

Please check the document version of this publication:

- A submitted manuscript is the version of the article upon submission and before peer-review. There can be important differences between the submitted version and the official published version of record. People interested in the research are advised to contact the author for the final version of the publication, or visit the DOI to the publisher's website.

- The final author version and the galley proof are versions of the publication after peer review.

- The final published version features the final layout of the paper including the volume, issue and page numbers.

Link to publication

\section{General rights}

Copyright and moral rights for the publications made accessible in the public portal are retained by the authors and/or other copyright owners and it is a condition of accessing publications that users recognise and abide by the legal requirements associated with these rights.

- Users may download and print one copy of any publication from the public portal for the purpose of private study or research.

- You may not further distribute the material or use it for any profit-making activity or commercial gain

- You may freely distribute the URL identifying the publication in the public portal.

If the publication is distributed under the terms of Article 25fa of the Dutch Copyright Act, indicated by the "Taverne" license above, please follow below link for the End User Agreement:

https://www.ou.nl/taverne-agreement

Take down policy

If you believe that this document breaches copyright please contact us at:

pure-support@ou.nl

providing details and we will investigate your claim.

Downloaded from https://research.ou.nl/ on date: 26 Apr. 2023 


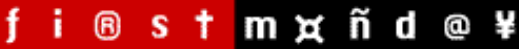

PEER-REVIEWED JOURNAL ON THE INTERNET

Understanding personal learning networks:

Their structure, content and the networking skills needed to optimally use them

by Kamakshi Rajagopal,

Desirée Joosten-ten Brinke,

Jan Van Bruggen,

and Peter B. Sloep

\begin{abstract}
Networking is a key skill in professional careers, supporting the individual's growth and learning. However, little is known about how professionals intentionally manage the connections in their personal networks and which factors influence their decisions in connecting with others for the purpose of learning. In this article, we present a model of personal professional networking for creating a personal learning network, based on an investigation through a literature study, semi-structured interviews and a survey.
\end{abstract}

\section{Contents}

Introduction

Methodology

The learner as orchestrator of her personal learning network

The personal learning network model

Discussion and conclusion: Supporting personal networking and future research

\section{Introduction}

In modern working life, professionals need to perform flexibly and independently in ever-changing environments (Castells, 2000). To be able to do this effectively, they depend on various lifelong learning skills, among others autonomous and self-directed learning. As they are partly supported in their learning by interaction with their peers, an essential life-long learning skill they need to develop, is the ability to find and to connect with relevant others, i.e., professional networking (Johnson, 2008; Nardi, et al., 2000).

We define the activity of professional networking as the act of making connections with other professionals, with or without the intention of making long-term ties with them (Compton, 2009; Tempest and Starkey, 2004). In our understanding, the skills at the centre of networking involve an ability to identify and understand other people's work in relation to one's own, and to assess the value of the connection with these others for potential future work. The result of networking is a personal professional network, i.e., an egocentric, personally and intentionally created network of people set up by an individual specifically in the context of her professional activities. This network gathers a heterogeneous circle of people, distributed across different groups and places, and connected to the individual with connections of varying degrees of strengths (Granovetter, 1983; Nardi, et al., 2000).

Professional networking offers various benefits. From the individual's perspective, it supports the development and growth of professionals' careers (Cross, et al., 2003; Dulworth, 2006; Krattenmaker, 2002). Your networks also allow you to find appropriate, constant support when the need arises (Haythornthwaite, 2002; Ru and Ortolano, 2009; Van Ryzin, et al., 2009). From the organisation's perspective, networking and networks are vital in innovation and crucial in linking to new trusted partners when dealing with changing business priorities (Birkinshaw, et al., 2007; Pulley and Wakefield, 2001; Vervest, et al., 2009). Networking supports group formation for the purpose of awareness-raising and/or socio-economic progress (see Compton, 2009; Fesko, 1997; Gupton and Slick, 1996; Hays, et al., 2003). Professional networking can also be used as a means to continuously support professionals' life-long learning in practice (Johnson, 2008). Once created, personal professional networks 
are platforms in which conversations and dialogue can occur, thus allowing for individual (non-formal) learning (Eraut, 2000). This learning is especially prevalent in practice, where tacit knowledge is built through experience and reflection and shared through social interaction with others (Bolhuis and Simons, 2001; Hearn and White, 2009). Furthermore, the ability to make conversations possible between people when needed is recognised as a key enabler of knowledge creation in organisational settings (Von Krogh, et al., 2000).

Both strong and weak connections contribute to the individual's learning: strong ties allow for active collaboration on knowledge creation, whereas weak ties are sources for new information, knowledge and ideas (Bell, 2010; Gargiulo and Benassi, 2000; Jones, 2008; Jones, et al., 2008; Ryberg and Larsen, 2008; Wenger, 1998). As the dichotomy of strong versus weak ties is not self-evident, more refinement is needed (Lin, 2008). For personal networks, Grabher and Ibert (2008) proposed a three-layered approach, consisting of a communality layer (strong ties), a sociality layer (weak ties) and a connectivity layer (very weak ties).

It has also been recognised that ties and networks can be intentionally built, created and maintained as resources for learning and working (Burt, 1992). The structure of a personal network can change in ways best benefiting the needs of professional learners throughout different stages of their careers (Margaryan, et al., 2009). By including weak links in their personal networks, learners can create an environment for learning (Kester and Sloep, 2009). We believe the intentionality of the professional is the strongest at the sociality layer, as contacts in this layer are the most mobile within someone's personal network. Depending on the intentions of the professional, these ties have the potential to become stronger connections or develop into even weaker ties. An individual can therefore create and orchestrate ties to effectively support learning needs and potentially use technology to support this network, effectively making it a personal learning network (PLN).

This article aims to understand how professionals determine the networking actions they undertake. In other words, how does the support offered by different ties in a professional's personal learning network change and evolve with the intentional actions of the professional? We present a model describing the act of personal professional networking for creating a personal learning network based on the results of a literature study of academic and informal resources and two empirical studies. After briefly presenting the research method, we will discuss the factors that influence the decisions professional learners take while building and navigating a personal learning network. This then results in a description of the Personal Learning Network model and related technology needs. Finally, we will discuss some directions for further research.

\section{Methodology}

In order to develop a model of how the dynamics of ties play out in supporting individual learning, we collected data from different sources. We first looked for existing research reports on professional networking, with a focus on relationship building and network building from an individual's personal perspective. The inclusion of informal literature (such as magazines and blog posts) enlightened us on the value of networking as experienced by individuals and gave us some tips and tricks from these professionals in practice. Our literature study identified an initial list of factors that influence networking decisions.

Additionally, two small-scale qualitative studies were conducted to establish the individuals' strategies to create, maintain and use their personal networks for learning. A first small-scale study used explorative semi-structured interviews with 10 interviewees, who had a minimum of five years experience in the social development sector working in projects on a daily or weekly basis. They were questioned on the project itself, their personal learning experiences regarding the project and the role of their personal networks in these experiences. The interviews, conducted in Dutch and English, were audio-recorded, transcribed and analysed in the following way: first, the texts were systematically screened for mentions of people; then, these passages were clustered into roles of other people in the learning experiences of the interviewee. From this first analysis, it emerged that interviewees differed greatly in the way they describe their contacts. This difference was deemed relevant and taken up in the results. Dutch quotes further on in this article have been translated into English. A second small-scale study was conducted consisting of short surveys at two networking events (the EAPRIL conference - 2010, in Lisbon and the Media and Learning Conference - 2010, in Brussels). Sixteen at random chosen participants were asked to consider their personal networking activities at the event, focusing on those contacts they expected to remain in touch with after the conference and their reported reasons for this. These reasons were coded with the initial factors identified in the literature study. The list was completed with additional factors that emerged as being significant from the survey. 


\section{The learner as orchestrator of her personal learning network}

Learning professionals can actively undertake measures to make the best use of the learning opportunities in their layered personal learning networks. They need to perform three important (primary) tasks that form the basis for all other further activities within the network: building connections (adding new people to the network so that there are resources available when a learning need arises); maintaining connections (keeping in touch with relevant persons); and activating connections with selected persons for the purpose of learning (Nardi, et al., 2000; Nardi, et al., 2002). In this section, we will present the factors influencing the decisions of a professional in these tasks. In doing this, we will also uncover the specific attitude of a professional that lies at the root of this type of learning.

\section{Factors influencing choices in building, maintaining and activating personal learning networks}

The literature search for factors that influence the stages of building, maintaining and activating connections revealed topics related to the context of networking. A clear value for professionals emerged: they design and navigate their network to bring them the most professional and educational benefit at each stage of their career (Dulworth, 2006; Cross, et al., 2003; Steiny and Oinas-Kukkonen, 2007). They undertake specific activities for networking, such as joining (online and face-to-face) professional associations, participating in conferences, workshops, seminars or networking events to meet new people or to reconfirm existing ties (Bauman, 2008; DeLeskey, 2003; Valenza and Johnson, 2008). In addition, increasingly, Web-based technologies play a role in connecting with new people (on social networking sites such as LinkedIn and Facebook) (Vermeiren, 2011) or for maintaining relations after events (Hamm, 2007). The literature study, however, gave little information on the practical strategies that encourage and establish successful professional relationship building. This was then researched by the survey and the in-depth interviews.

The following factors emerged from the result of the literature study, survey and interviews. We have grouped the factors into three main sections: (i) factors relating to the professional learner's personal interests; (ii) factors relating to the contact and their relationship with the learner; and, (iii) external characteristics of the work environment.

The first group of factors relates to the professional learner's personal professional interests, largely determined by certain immediate professional needs.

- Communality. While creating new connections, people look out for common ground with an unknown person. This can be in the form of topics of interest, organisation or common connections (network) (Adamic and Adar, 2005; Douglas, 1994). The survey results indicated that professionals also use communality on topic and organisation to decide whom to maintain connections with in a personal learning network. In activating a connection within a personal learning network, the key factor that emerged from the survey is the suitability of that person's experience or expertise for the particular topic or need sought (cf., experts, zone of proximal development, etc.). The personal attachment between the individual and the person also plays an undeniable role. The location where new connections are created is also important: a trusted, known environment is often chosen to expand networks (Paulos and Goodman, 2004).

The next group of factors on contact's qualities relate to features of the contact in question (the contact's organisation, network or reputation), or indicate the personal attachment between the learner and the contact (benevolence, like-mindedness). They can also indicate the professional's assessment of the potential value of the tie (potential for collaboration or learning).

- Organisation of the contact. The organisation the contact belongs to may influence choices made regarding the nature of a tie (Morrison, 2002).

- Network of a contact. The network of a contact may also be a decisive factor in the management of professional ties (Jackson and Rogers, 2007).

- Reputation. Reputation plays a role in network ties with others in general, and also in the creation of a new connection (Davies, 2003; Podolny and Baron, 1997).

- Benevolence. Another factor that plays a crucial role is benevolence or the general "good contact" between an individual and a new contact (Rusman, et al., 2010). People connect with others whom they like or trust, or with whom they feel a particular connection.

- Like-mindedness. The surveyed interviewees often mentioned that sharing a common vision on the domain of work creates a trusted platform where they feel comfortable further pursuing the conversation. Further discussions could reveal more communality, and thereby new scope for connecting. Building new connections in a personal network consists of identifying relevant skills and competence in others and establishing a trusted platform through conversation where the potential of the connection can be explored. 
- Real potential for collaboration. Discussions could deal with the details of common interest and reveal a clear potential for collaboration.

- Real potential for learning. More than that, through an extended conversation, the interviewees indicated they could identify a potential for learning through maintaining the connection.

The final group of factors relate to external characteristics of the work environment in which the tie between the professional learner and the contact is situated.

- Trends in work environment. The professional interests of a learner can be largely determined by circumstances and trends in the work environment of the professional (Birkinshaw, et al., 2007). For example, the increasing popularity of a particular domain might make it more relevant to connect to ties working in that domain.

Although these nine factors emerged from the studies, it was not possible to identify conclusively to what extent each factor influences each stage of networking. However, the results show that benevolence, like-mindedness and real potential for collaboration and learning play an important role in the building phase. Further research is necessary to refine this aspect of the model. Figure 1 illustrates the three stages of the networking process, with the factors that influence each of these stages.

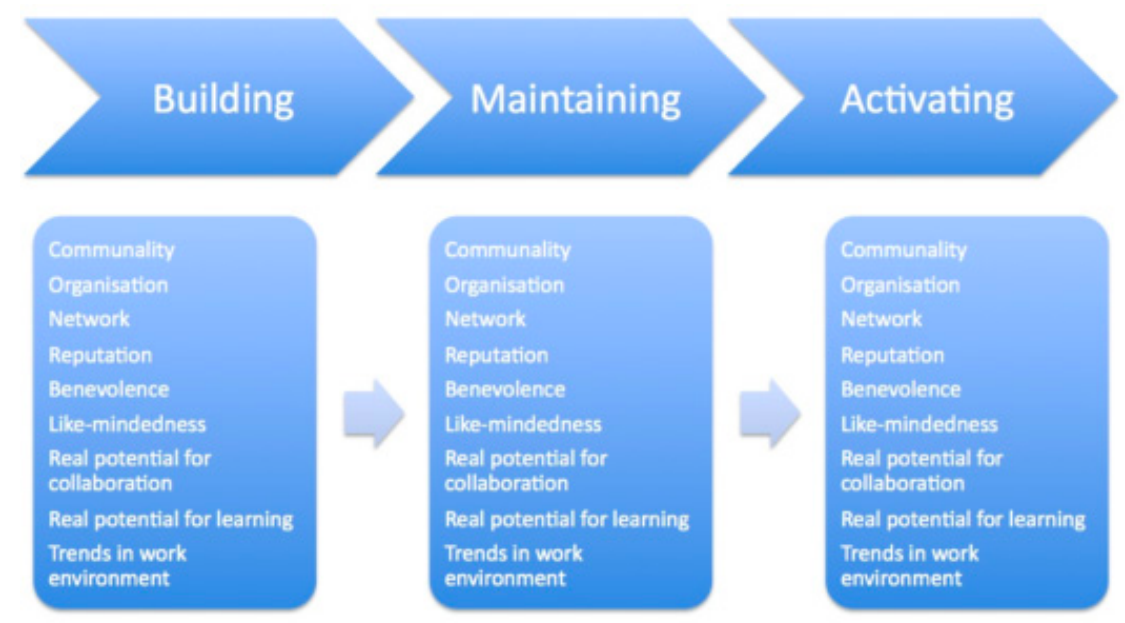

Figure 1: Three stages of the networking process with factors influencing decisions.

\section{Networking attitude of a learner}

Although factors identified in previous studies related to a learner's practical decisions, informal literature and the in-depth interviews revealed that networking itself is linked to a deeper metacognitive level, namely, the attitude of the learner (Vermeiren, 2008).

When asked to reflect on their learning experiences and the role of others in those learning processes, interviewees displayed clear differences in the way they interact with contacts in their personal networks and the way they learn from these interactions. The results are presented here with quotes from the interviews.

The first observation is that some interviewees were able to describe the contributions of their contacts to their learning in a much more detailed and contextualised way than did others: the learning experiences were identified with the contact's qualities. Note the following example from an interviewee below, who appreciates having access to a wide network of contacts:

"[...] that we have the possibility to ask advice from certain people. And one person is more suitable for a certain type of advice, and another person for another type of advice, but it does help a lot. It certainly helps."

Also, they portray some insight into their contact's strengths and weaknesses as well as of their own:

"[...] because she not only asked, but she also had a vision behind those questions. And her vision and my vision correspond, they fit. And a vision that corresponds, that is very important. If you want a project, you absolutely need to be able to fall back on people who have the same vision as you. [...] You need 
to want to evolve in the same direction. And that's clearly the case with her."

"I like people who want to go against the tide, without wanting to be extreme in that. But it shows that they have a particular character and a certain dare to go further. I think that is important."

These narratives presented a clear picture of the contacts in the learner's personal network the strong, weak and very weak ties - and their contributions to learning. However, this contextualising of others' experiences and their relevance for own learning purposes is not general. For example, see the quote below from another interviewee:

"You have a school for the rich, a beautiful building, I can show you photos later, and then at 500m distance, you have a school for the poor and I asked: 'are you not just reinforcing this difference?' But they said, 'on the one hand, yes, we are, but on the other hand, this is the only way the children of the poor people have access to education.' [...] what they also do is morning assembly, which is very important, they do that together. So you see, on the one hand you can say that they are reinforcing the difference, but on the other it does give them the opportunity to go to school."

This interviewee also interacts with others to understand the situation, but these contacts remain hidden in the narrative, purely appearing as sources of information or general opinion.

The second observation is that the effects of networking are not limited to face-to-face interactions with the contacts: even when others are not present, their words, messages and perspectives can influence the reflections of the learner. This results from two conditions: (i) the reflective behaviour of the learner; and, (ii) the extent to which the learner views the contacts as visible entities (or learning resources) in her personal network. Reflective behaviour with regard to one's own practice is recognised in the literature (Bolhuis and Simons, 2001; Schön, 1990). In our opinion, detailed contextualising of a contact is an indication that the contact is visible in the learner's personal network. For example, the following learning experience by one of the interviewees describes the results of her reflection together with others. However, despite requests for further clarification, she did not develop a further detailing of various perspectives on the issues in the interview:

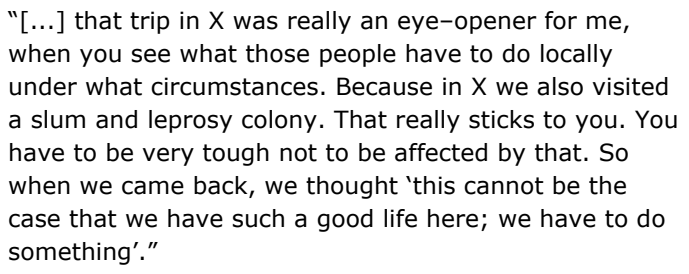

Although this interviewee used reflection to develop her understanding, she did not identify the contributions of various contacts to her learning nor provide further context for those contributions. Interviewees with a seemingly further evolved networking skill use the informational and knowledge building benefits of their personal learning network almost on a daily basis, affecting all aspects of their professional life. Each contact is seen as a potential person to learn from or to collaborate with. In this sense, networking can be viewed as an attitude to learning and working, i.e., the position taken towards learning and the role that their networks and networking plays in that learning.

These two observations allow us to conclude that networking for networked learning is not only a skill to be developed, but also an attitude towards learning to be cultivated. The interviews confirmed that networking revolves around a complex ability of (i) recognizing and identifying the other's qualities; and, of (ii) making (valuable) associations of these qualities with the learner's own qualities that could take place when interacting with a contact or even in the contact's absence. Learners have different levels of proficiency in this skill, but can also differ in the actual application of the skill, due to the attitude with which they approach learning. Proficient networkers use dedicated events and environments where networking has the prime focus (such as professional conferences, seminars and, more recently, online social networking sites) to trigger their mind into making valuable associations.

The interviews supported findings that this attitude emerges with people who a) experience the value of their network at first hand (Hamm, 2007) and/or people who b) reflect on their work and learning in a broader perspective than their day-to-day practice (Margaryan, et al., 2009). This is exemplified by the quote from one interviewee below:

"[...] yes, no one is free of the luxury to ask someone for advice. I think it is important for everyone to be able to ask advice. And that it is also a privilege to be able to 
ask advice. There is nothing wrong with it. On the contrary, I think it is an advantage rather than a handicap to be able to ask advice..."

\section{The personal learning network model}

The nine factors that influence personal professional networking (identified above), as well as the networking attitude that governs networking activities (described above) can be schematically represented in a personal professional networking model (illustrated in Figure 2).

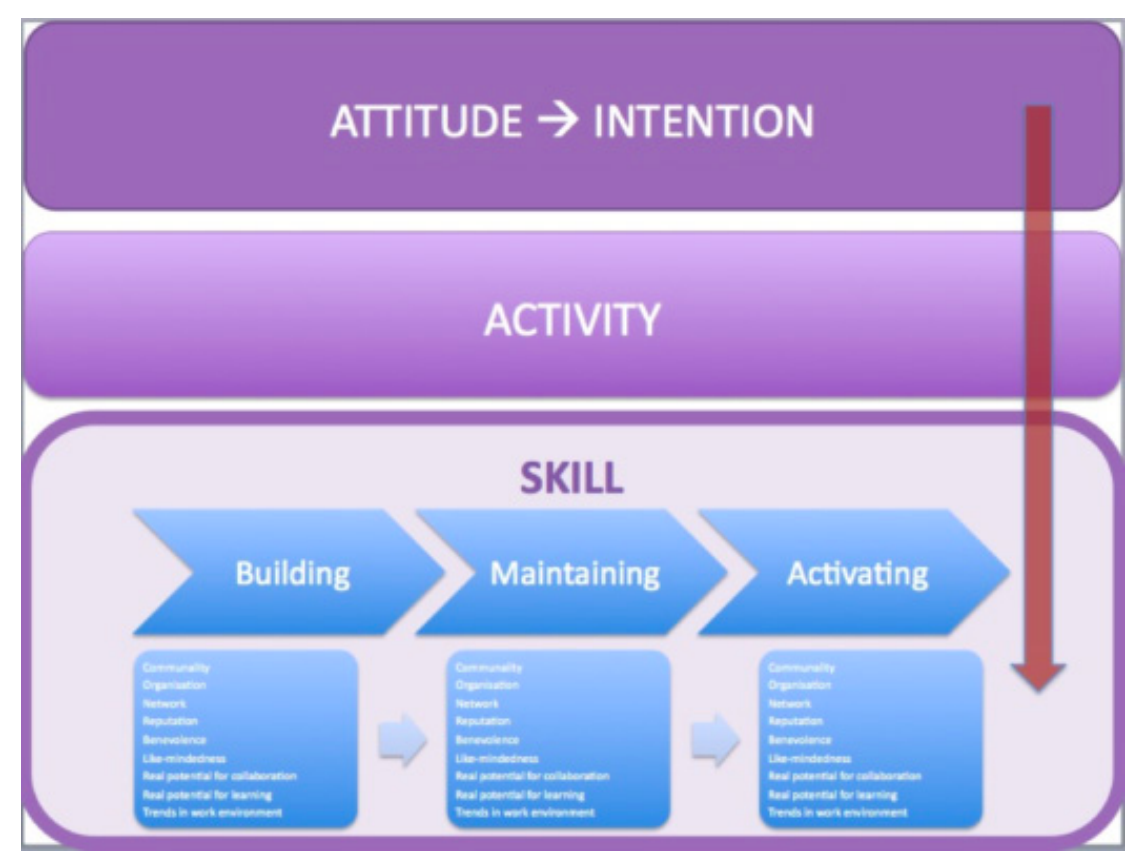

Figure 2: Personal professional networking model.

This three-layered model relates the attitude of a professional learner towards networking to the actual networking skills she displays in day-to-day practice. Attitudes and skills are different types of qualities: an attitude is something of the mind, a perspective with which a person views the world; a skill is a practical, developable ability to do something. Because of this difference, it is not possible to directly link the two layers. To do so, requires two important intermediary steps in our view. The first one is the translation of this attitude in the mind to a deliberate intention (attitude-to-intention layer). When professionals have developed an attitude of approaching their professional life and learning in a networked way, they build, maintain and activate their contacts intentionally.

The second step is to translate that intention into actions (activity layer). The professional's intention manifests itself through the activity of networking, where the professional engages in practices enabling and supporting networking. These include activating strong ties (e.g., brainstorming with colleagues), activating weak ties (e.g., reaching a known contact), building or maintaining weak and very weak ties (e.g., joining networking events or an online social networking site). The activity of networking depends on the complex skill of being able to make associations between the contact's qualities and one's own (skill layer). This complex skill is in turn influenced by the different factors identified earlier in this article at the different phases of networking. As such, the attitude trickles down as it were to affect the professional's actions and the required skills.

A personal learning network (PLN) is a network set up by an individual specifically in the context of her professional activities through online platforms to support her professional non-formal learning needs. Therefore, a professional who intentionally builds, maintains and activates her strong, weak and very weak ties with contacts within her personal network for the purpose of improving her learning - and uses technology to support this activity - is creating a personal learning network. The learner at the centre orchestrates the whole environment, browsing, selecting and choosing the most relevant information resources (Conole, et al., 2008; Schaffert and Hilzensauer, 2008; Wilson, et al., 2006). To support 


\section{Discussion and conclusion: Supporting personal networking and future research}

Technologies included in PLNs offer basic to advanced functionalities (such as search, access to content, user-made content classification, personal knowledge creation and presentation and communication with peers and others), which learners can employ, change and adapt to suit their learning needs (Attwell, et al., 2009). These tools allow learners to structure and manage the complex environment of people and content around themselves according to their own personal preferences.

Currently, technological solutions exist supporting different aspects of the networking model. In the skill layer, existing technologies for social network management on social networking platforms focus on:

- enhancing communication with people in the network (e-mail; communication functionality on networking platform; privacy management to determine specific contacts);

- remaining "in touch" with known people in the network: informal information pull to remain connected with others in the network;

- positioning an individual in the network; and,

- finding hidden people and expertise in the network: basic user search functionality (name, profile characteristics); advanced functionality, e.g., recommendation of peers (Guy, et al., 2009; Sie, et al., 2011), identification of relevant people to help with a particular learning problem (Fetter, et al., 2010; Van Rosmalen, 2008).

Although these functionalities fulfill the general stages of networking, technology does not yet support the deeper understanding of networking practice. For example, the distinction between strong, weak and very weak ties with respect to content of the relationship is not always visible in online social networking sites. The technology therefore offers minimal support in developing ties in a meaningful way. Also at the level of networking activity, technology provides common platforms where people can connect (general social networking sites such as LinkedIn, Facebook, Hyves and Twitter; domain-specific social networking sites, such as UNESCO-UNEVOC eForum and the Zunia network; event-specific social networking sites such as platforms for online conferences, workshops and webinars). Face-to-face events are also increasingly supported by Web-based technologies, to enable people to make more valuable weak ties on a longer term (see for example, the "Follow the Sun - Learning Futures Festival Online 2011" initiative (Follow the Sun, 2011)).

A personal learning network model, including the technological support for the different aspects of networking, is illustrated in Figure 3. 


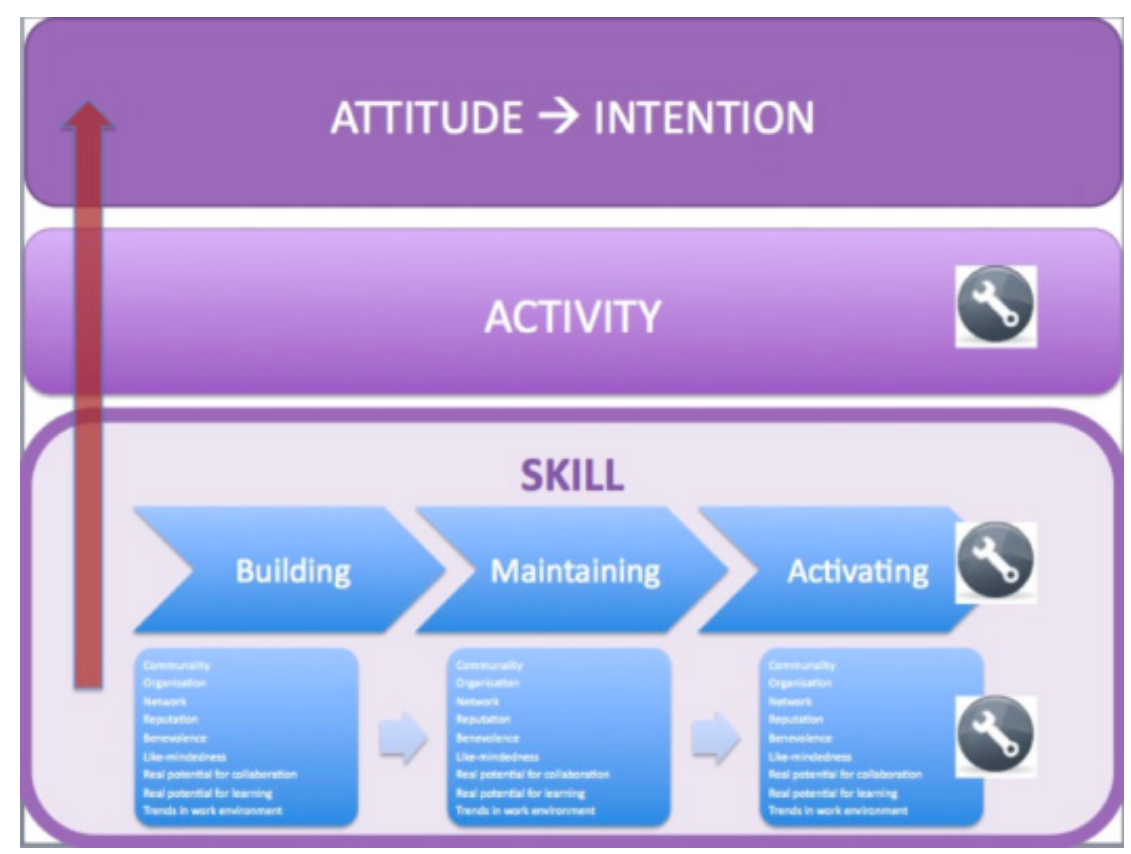

Figure 3: Personal learning network model.

Although technological solutions facilitate many aspects of networking, it is unclear if technology supports or, indeed, affects the networking attitude of professionals and/or the related intention to build, maintain and activate the strong and weak ties in their personal network for the purpose of learning. This brings us to the next steps to take.

Further research steps include studies investigating the networking practice of professionals to gain a better understanding of the networking attitude; a further development of technology to support professionals better in identifying relevant others and in developing relations online as and when necessary. Finally, an investigation is also necessary into the effects of networking technology on the networking attitude of professionals. $\mathbf{E M}$

\section{About the authors}

Kamakshi Rajagopal received a Master's degree in Germanic Languages (computational linguistics) and an Advanced Master's in Artificial Intelligence (Speech \& Language Technology) from K.U.Leuven (BE). She worked as a corpus-linguist at the UCL, Louvain-la-Neuve (BE) on the Learners Corpus for Dutch as a Foreign Language. In 2005, she joined K.U.Leuven as a researcher/project manager working on European-funded projects and piloting new applications of ICT and multimedia in mainstream education. Since 2009, she is working as a researcher at the Centre for Learning Sciences and Technologies (CELSTEC) at the Open Universiteit (NL). In her Ph.D. studies, she investigates how professionals create and manage their personal learning networks as resources for their learning and how technology can effectively support professionals in this type of learning.

Direct comments to kamakshi [dot] rajagopal [at] ou [dot] $\mathrm{nl}$

Desirée Joosten-ten Brinke is associate professor in contemporary testing and assessment at Fontys, University of Applied Sciences for teacher trainers, and researcher and assessment expert at Centre for Learning Sciences and Technologies (CELSTEC) at the Open University of the Netherlands. Her research focus is on assessment of prior learning, e-assessment, professional development of teachers in assessment, and quality of testing and assessment procedures. She is involved in several projects in which feedback on (self-) assessment tasks in an e-learning environment to improve personal development is emphasized. The context of her work includes primary, secondary and higher (vocational) education in a broad domain of subjects (f.e, computer science, cultural science, Spanish ...). She is a member of the editorial commission of a Dutch journal on testing and assessment.

E-mail: desiree [dot] joosten-tenbrinke [at] ou [dot] $\mathrm{nl}$

Dr. Jan Van Bruggen is an associate professor at CELSTEC where he leads one of the clusters of the learning networks program and a lector at Fontys University for Applied Science. His research interests are in the areas of networked learning, computer-supported collaborative learning and development of teaching expertise.

E-mail: jan [dot] vanbruggen [at] ou [dot] $\mathrm{nl}$ 
Dr. Peter B. Sloep is full professor in Technology Enhanced Learning at the Centre for Learning Sciences and Technologies (CELSTEC) at the Open University of the Netherlands and programme director of its R\&D programme on Networked Learning. His research encompasses such topics as networked learning, learning design, learning objects and open educational resources, as well as knowledge sharing and creative collaboration in communities and networks. He has co-authored more than 100 peer-reviewed publications in scholarly journals and conference proceedings. He has authored or edited three books and supervises $10 \mathrm{Ph}$.D. candidates, participates in the editorial board of several journals, among which ALT-J, several IEEE journals, Computers in Human Behavior. Sloep is a frequent speaker at national and international conferences. He serves on the editorial board of Research in Learning Technology, frequently reviews papers and book proposals for various journals and conferences in the TEL field, and has reviewed proposals for the Canadian, U.S. and Dutch national research agencies. He is the founding chair of the Technical Committee Learning Technology of the Dutch Standards Organisation (NEN). See, for a complete CV, http://pbsloep.nl/.

E-mail: peter [dot] sloep [at] ou [dot] nl

\section{Acknowledgements}

Parts of the article present research conducted under the Language Technologies for Lifelong Learning (LTfLL) project (2008-2011), which was co-funded by the European Union under the Information and Communication Technologies (ICT) theme of the 7th Framework Programme for R\&D (LTfLL - 2008 - 212578). We would also like to thank the 10 participants who took part in the in-depth interviews for this study. We are also grateful to the participants and organizers of the EAPRIL conference (2010) and the Media and Learning Conference (2010), who contributed to the survey.

\section{References}

Lada Adamic and Eytan Adar, 2005. "How to search a social network," Social Networks, volume 27, number 3, pp. 187-203.

Graham Attwell, John Cook and Andrew Ravenscroft, 2009. "Appropriating technologies for contextual knowledge: Mobile personal learning environments," In: Miltiadis D. Lytras, Patricia Ordóñez de Pablos, Ernesto Damiani, David Avison, Ambjörn Naeve and David G. Horner (editors). Best practices for the knowledge society: Knowledge, learning, development and technology for all. Communications in Computer and Information Science, volume 49. Berlin: Springer-Verlag, pp. 15-25.

Sheri Bauman, 2008. "To join or not to join: School counselors as a case study in professional membership,\&tdquo; Journal of Counseling and Development, volume 86, number 2, pp. 164-178.

Frances Bell, 2010. "Network theories for technology-enabled learning and social change: Connectivism and actor network theory," In: Lone Dirckinck-Holmfeld, Vivie Hodgson. Chris Jones, Maarten de Laat, David McConnell and Thomas Ryberg (editors). Proceedings of the Seventh International Conference on Networked Learning 2010 (3-4 May, Aalborg, Denmark), pp. 526-533.

Julian Birkinshaw, John Bessant and Rick Delbridge, 2007. "Finding, forming, and performing: Creating networks for discontinuous innovation," California Management Review, volume 49, number 3, pp. 67-84.

Sanneke Bolhuis and Robert-Jan Simons, 2001. "Naar een breder begrip van leren," In: Rob Poell and Joseph Kessels (editors). Human resource development Organiseren van het leren. Alphen aan den Rijn: Uitgeverij Samsom. pp. 37-51.

Ronald S. Burt, 1992. "The social structure of competition," In: Nitin Nohria and Robert G. Eccles (editors). Networks and organizations: Structure, form, and action. Boston: Harvard Business School Press, pp. 57-91.

Manuel Castells, 2000. The rise of the network society. Oxford: Blackwell.

Michele Compton, 2009. "Cast your net: Networking best practices and beyond," Women In Business, volume 61, number 2, pp. 30-31.

Gráinne Conole, Maarten de Laat, Teresa Dillon and Jonathan Darby, 2008. "'Disruptive technologies', 'pedagogical innovation': What's new? Findings from an in-depth study of students' use and perception of technology," Computers \& Education, volume 50, number 2, pp. 511-524.

Rob Cross, Thomas H. Davenport and Susan Cantrell, 2003. "The social side of performance," 
Sloan Management Review, volume 45, number 1, pp. 20-24.

William Davies, 2003. You don't know me, but ... Social capital and social software. London: Work Foundation.

Kathleen DeLeskey, 2003. "Factors affecting nurses" decisions to join and maintain membership in professional associations," Journal of PeriAnesthesia Nursing, volume 18, number 1 , pp. 8-17.

William Douglas, 1994. "The acquaintanceship process: An examination of uncertainty, information seeking, and social attraction during initial conversation," Communication Research, volume 21, number 2, pp. 154-176.

Michael Dulworth, 2006. "Enhancing personal and professional development: The role of peer networks," Employment Relations Today, volume 33, number 3, pp. 37-41.

Michael R. Eraut, 2000. "Non-formal learning and tacit knowledge in professional work," British Journal of Educational Psychology, volume 70, number 1, pp. 113-136.

Facebook, at http://www.facebook.com, accessed 31 December 2011.

Sheila Fesko, 1997. "Unrealized potential: Differing employment outcomes for individuals with mental retardation and other disability groups," at http://www.communityinclusion.org Larticle.php?article id=75\&staff id=8, accessed 25 March 2011.

Sibren Fetter, Adriana Berlanga and Peter B. Sloep. 2010. "Using ad hoc transient communities to strengthen social capital: Design considerations," In: Lone Dirckinck-Holmfeld, Vivie Hodgson. Chris Jones, Maarten de Laat, David McConnell and Thomas Ryberg (editors). Proceedings of the Seventh International Conference on Networked Learning 2010 (3-4 May, Aalborg, Denmark), pp. 151-158.

Follow the Sun, 2011. "Online Learning Futures Festival 2011," at http://www2.le.ac.uk /departments/beyond-distance-research-alliance/festival, accessed 4 May 2011.

Martin Gargiulo and Mario Benassi, 2000. "Trapped in your own net? Network cohesion, structural holes, and the adaptation of social capital," Organization Science, volume 11, number 2, pp. 183-196.

Gernot Grabher and Oliver Ibert, 2006. "Bad company? The ambiguity of personal knowledge networks," Journal of Economic Geography, volume 6, number 3, pp. 251-271.

Mark Granovetter, 1983. "The strength of weak ties: A network theory revisited," Sociological Theory, volume 1, pp. 201-233.

Sandra Lee Gupton and Gloria Appelt Slick, 1996. Highly successful women administrators: The inside stories of how they got there. Thousand Oaks, Calif.: Corwin Press.

Ido Guy, Inbal Ronen and Eric Wilcox, 2009. "Do you know? Recommending people to invite into your social network," IUI '09: Proceedings of the 13th International Conference on Intelligent User Interfaces. New York: ACM, pp. 77-86.

T. Hamm, 2007. "The one hour project: Touch base with professional and local acquaintances," at http://www.thesimpledollar.com/2007/09/14/the-one-hour-project-touch-base-withprofessional-and-local-acquaintances/, accessed 24 March 2011.

Richard Hays, Shona Wynd, Craig Veitch and Lisa Crossland, 2003. "Getting the balance right? GPs who chose to stay in rural practice," Australian Journal of Rural Health, volume 11, number 4, pp. 193-198.

Caroline Haythornthwaite, 2002. "Building social networks via computer networks: Creating and sustaining distributed learning communities," In: K. Ann Renninger and Wesley Shumar (editors). Building virtual communities: Learning and change in cyberspace. Cambridge: Cambridge University Press, pp. 159-190.

Simon Hearn and Nancy White, 2009. Communities of practice: Linking knowledge, policy and practice. London: Overseas Development Institute, and at http://www.odi.org.uk/resources /download/1129.pdf, accessed 22 Dercember 2011.

Hyves, at http://www.hyves.nl, accessed 31 December 2011.

Matthew O. Jackson and Brian W. Rogers, 2007. "Meeting strangers and friends of friends: How random are social networks?" American Economic Review, volume 97, number 3, pp. 890-915.

Mike Johnson, 2008. "Expanding the concept of networked learning," In: Vivien Hodgson, Chris Jones, Theodoros Kargidis, David McConnell, S. Retalis, Demosthenes Stamatis, and Maria Zenios (editors). Proceedings of the Sixth International Conference on Networked Learning (5-6 May, Halkidiki, Greece), pp. 154-161.

Chris Jones, 2008. "Networked learning: Weak links and boundaries," Journal of Computer Assisted Learning, volume 24, number 2, pp. 87-89. 
Chris Jones, Debra Ferreday and Vivien Hodgson, 2008. "Networked learning, a Relational Approach: Weak and strong ties," Journal of Computer Assisted Learning, volume 24, number 2, pp. 90-102.

Liesbeth Kester and Peter B. Sloep, 2009. "Knowledge dating and knowledge sharing in ad-hoc transient communities," In: Rob Koper (editor). Learning network services for professional development. Berlin: Springer-Verlag, pp. 30-44.

Tom Krattenmaker, 2002. "A blueprint for constructing a personal and professional network," Harvard Management Communication Letter, volume 5, number 4, pp. 3-4.

Nan Lin, 2008. "A network theory of social capital," In: Dario Castiglione, Jan W. van Deth and Guglielmo Wolleb (editors). The handbook on social capital. Oxford: Oxford University Press, pp. 50-69.

LinkedIn, at http://www.linkedin.com, accessed 31 December 2011.

Anoush Margaryan, Colin Milligan and Allison Littlejohn, 2009. "Self-regulated learning and knowledge sharing in the workplace: Differences and similarities between experts and novices," Proceedings of the Sixth International Conference on Researching Work and Learning (RWL6) (28 June-1 July, Roskilde, Denmark).

Elizabeth Wolfe Morrison, 2002. "Newcomers' relationships: The role of social network ties during socialization," Academy of Management Journal, volume 45, number 6, pp. $1,149-1,160$.

Bonnie Nardi, Steve Whittaker and Heinrich Schwarz, 2002. "NetWORKers and their activity in intensional networks," Computer Supported Cooperative Work (CSCW), volume 11, numbers $1-2$, pp. 205-242.

Bonnie A. Nardi, Steve Whittaker and Heinrich Schwarz, 2000. "It's not what you know, it's who you know: Work in the information age," First Monday, volume 5, number 5, at http://firstmonday.org/htbin/cgiwrap/bin/ojs/index.php/fm/article/view/741/650, accessed 4 May 2011.

Eric Paulos and Elizabeth Goodman, 2004. "The familiar stranger: Anxiety, comfort, and play in public places," In: Elizabeth Dykstra-Erickson and Manfred Tscheligi (editors). CHI 2004: Proceedings of the SIGCHI Conference on Human Factors in Computing Systems. New York: ACM, p. 223-230.

Joel M. Podolny and James N. Baron, 1997. "Resources and relationships: Social networks, mobility, and satisfaction in the workplace," American Sociological Review, volume 62, number 5, pp. 673-693.

Mary Lynn Pulley and Michael Wakefield, 2001. Building resiliency: How to thrive in times of change. Greensboro, N.C.: Center for Creative Leadership.

Jiang Ru and Leonard Ortolano, 2009. "Development of citizen-organized environmental NGOs in China," Voluntas: International Journal of Voluntary and Nonprofit Organizations, volume 20, number 2, pp. 141-168.

Ellen Rusman, Jan Van Bruggen, Peter B. Sloep, Martin Valcke and Rob Koper, 2010. "The mind's eye on personal profiles; How to inform initial trustworthiness assessments in virtual project teams," In: Gwendolyn Kolfschoten, Thomas Herrmann and Stephan Lukosch (editors), Collaboration and technology: Proceedings of the 16th International Conference, CRIWG 2010 (20-23 September, Maastricht). Lecture Notes in Computer Science, volume 6257. Berlin: Springer-Verlag, pp. 297-304.

Thomas Ryberg and Malene Charlotte Larsen, 2008. "Networked identities: Understanding relationships between strong and weak ties in networked environments," Journal of Computer Assisted Learning, volume 24, number 2, pp. 103-115.

Sandra Schaffert and Wolf Hilzensauer, 2008. "On the way towards personal learning environments: Seven crucial aspects," elearningpapers, volume 9, at http://www.elearningeuropa.info/files/media/media15971.pdf, accessed 4 May 2011.

Donald A. Schön, 1990. Educating the reflective practitioner. San Francisco: Jossey-Bass.

Rory L.L. Sie, Marlies Bitter-Rijpkema and Peter B. Sloep, 2011. "What's in it for me? Recommendation of peers in networked innovation," Journal of Universal Computer Science, volume 17, number 12, pp. 1.659-1.672.

Donald Steiny and Harri Oinas-Kukkonen, 2007. "Network awareness: Social network search, innovation and productivity in organisations," International Journal of Networking and Virtual Organisations, volume 4, number 4, pp. 413-430.

Sue Tempest and Ken Starkey, 2004. "The effects of liminality on individual and organizational learning," Organization Studies, volume 25, number 4, pp. 507-527.

Twitter, at http://www.twitter.com, accessed 31 December 2011. 
UNESCO-UNEVOC eForum, at http://www.unevoc.de/eforum.php, accessed 31 December 2011.

Joyce Valenza and Doug Johnson, 2008. "Reboot camp: Get into tech shape," School Library Journal, volume 13, number 1, at http://www.schoollibraryjournal.com/article /CA6555547.html, accessed 4 May 2011.

Gregg G. Van Ryzin, Seth Grossman, Laurie DiPadova-Stocks and Erik Bergrud, 2009. "Portrait of the social entrepreneur: Statistical evidence from a U.S. panel," Voluntas: International Journal of Voluntary and Nonprofit Organizations, volume 20, number 2, pp. 129-140.

Peter Van Rosmalen, 2008. "Supporting the tutor in the design and support of adaptive e-learning," Proefschrift Open Universiteit Nederland.

Jan Vermeiren, 2011. "The networking coach's opinion," at http://janvermeiren.wordpress.com/, accessed 24 April 2011.

Jan Vermeiren, 2008. Let's connect: A practical guide for highly effective professional networking. New York: Morgan James.

P.H. Vervest, D.W. van Liere, and A.H. Dunn, 2009. "The network factor - How to remain competitive," In: Peter H. Vervest, Diederik Willem Van Liere and Li Zheng (editors). The network experience: New value from smart business networks. Berlin: Springer-Verlag, pp. 15-35.

Georg Von Krogh, Kazuo Ichijo and Ikujiro Nonaka, 2000. Enabling knowledge creation: How to unlock the mystery of tacit knowledge and release the power of innovation. Oxford: Oxford University Press.

Etienne Wenger, 1998. Communities of practice: Learning, meaning, and identity. Cambridge: Cambridge University Press.

Scott Wilson, Oleg Liber, Mark Johnson, Phil Beauvoir, Paul Sharples and Colin Miligan, 2006. "Personal learning environments: Challenging the dominant design of educational systems," In: Martin Memmel, Eric Ras, Stephan Weibelzahl, Daniel Burgos, Daniel Olmedilla and Martin Wolpers (editors). Joint International Workshop on Professional Learning, Competence Development and Knowledge Management - LOKMOL and L3NCD (2-4 October, Crete).

Zunia network, at http://zunia.org, accessed 31 December 2011.

\section{Editorial history}

Received 27 August 2011; accepted 23 December 2011.

Copyright () 2012, First Monday.

Copyright (๑) 2012, Kamakshi Rajagopal, Desirée Joosten-ten Brinke, Jan Van Bruggen, and Peter B. Sloep. All rights reserved.

Understanding personal learning networks: Their structure, content and the networking skills needed to optimally use them

by Kamakshi Rajagopal, Desirée Joosten-ten Brinke, Jan Van Bruggen, and Peter B. Sloep. First Monday, Volume 17, Number 1 - 2 January 2012

http://www.uic.edu/htbin/cgiwrap/bin/ojs/index.php/fm/rt/printerFriendly/3559/3131 